\section{Preparation of PCR- Quality Mouse Genomic DNA with Hot Sodium Hydroxide and Tris (HotSHOT)}

BioTechniques 29:52-54 (July 2000)

Preparation of mouse genomic DNA for PCR is costly and laborious, primarily because of the difficulty in physically separating DNA from other tissue components. This level of purification is unnecessary for many PCR applications. A simple alternative, lysis in an alkaline reagent and neutralization with a suitable buffer, has been used to prepare genomic DNA from buccal swabs, whole blood, semen and forensic samples collected from humans (2). A few modifications of this protocol make it possible to prepare PCR-quality mouse genomic DNA with a brief incubation in hot sodium hydroxide and $\mathrm{pH}$ adjustment with a Tris solution (HotSHOT). The HotSHOT method is rapid, inexpensive and may be carried out in 96-well plates, making it amenable to automation and high-throughput genotyping.

The reagents for HotSHOT DNA preparation are simple to prepare. An alkaline lysis reagent with $25 \mathrm{mM}$ $\mathrm{NaOH}, 0.2 \mathrm{mM}$ disodium EDTA and a $\mathrm{pH}$ of 12 is prepared by dissolving the salts in water without adjusting the $\mathrm{pH}$. A neutralizing reagent with $40 \mathrm{mM}$ Tris- $\mathrm{HCl}$ and a $\mathrm{pH}$ of 5 is prepared by dissolving Tris- $\mathrm{HCl}$ (not Tris base) in water without adjusting the $\mathrm{pH}$.Tissue samples (neonatal mouse toes, ear punches, $0.2-\mathrm{cm}$ tail snips or $25-\mathrm{mg}$ pieces of spleen) are collected into a 96-well thermal cycler plate or thermal cycler strip tubes. The tissue sample must be small; too large a sample can cause the method to fail. Alkaline lysis reagent $(75 \mu \mathrm{L}$ is added to the samples and heated to $95^{\circ} \mathrm{C}$ for $10 \mathrm{~min}$ to $1 \mathrm{~h}$. The undissolved tissue does not interfere with PCR. After heating, samples are cooled to $4^{\circ} \mathrm{C}$, and $75 \mu \mathrm{L}$ neutralizing reagent are added to each sample. One to five microliters of the final preparation are used per each $10-\mu \mathrm{L}$ PCR volume. The combination of the alkaline lysis and neutralizing reagents yields a buffer consisting of $20 \mathrm{mM}$ Tris- $\mathrm{HCl}$ (pH 8.1) and 0.1 mM EDTA, which is similar to a common DNA storage buffer.

We have used this technique to prepare DNA for hundreds of PCR assays and find it remarkably consistent. Based on our initial success, we tested the method with tissues commonly used as a source of mouse genomic DNA. Toes from neonatal mice, $0.2-\mathrm{cm}$ tail snips from weanling mice, ear punches from adult mice and small pieces of spleen (about $25 \mathrm{mg}$ ) from adult mice were placed in thermal cycler strip tubes with $75 \mu \mathrm{L}$ alkaline lysis reagent added to each sample. Samples were heated to $95^{\circ} \mathrm{C}$ for $10,20,30$ or $60 \mathrm{~min}$, chilled to $4^{\circ} \mathrm{C}$ and $75 \mu \mathrm{L}$ neutralizing reagent were added to each tube. The yield of soluble DNA was measured by a fluorometric assay (1).

The performance of HotSHOT DNA in PCR was tested by amplifying a 182bp PCR product and comparing the performance of DNA prepared by proteinase $\mathrm{K}$ digestion, followed by phenol:chloroform extraction and ethanol precipitation (3). In this experiment, $1.5 \mu \mathrm{L}$ HotSHOT DNA was combined with $8.5 \mu \mathrm{L}$ PCR mixture. Forward and $\mathrm{nM}$ each with PCR buffer, $3 \mathrm{mM}$ $\mathrm{MgCl}_{2}, 0.2 \mathrm{mM}$ each dATP, dCTP, reverse primers were combined at 200

dGTP and dTTP, 0.12 U Taq DNA polymerase (Promega, Madison, WI, USA), in a $10-\mu \mathrm{L}$ volume. Reactions were covered with $10 \mu \mathrm{L}$ mineral oil and amplified in a PTC-100 ${ }^{\mathrm{TM}}$ thermal cycler (MJ Research, Watertown, MA, USA) for 40 cycles at $95^{\circ} \mathrm{C}$ for $40 \mathrm{~s}$ and $60^{\circ} \mathrm{C}$ for $45 \mathrm{~s}$. Following amplification, $10 \mu \mathrm{L}$ loading dye were added to each well $(4 \mu \mathrm{L} 60 \%$ sucrose and $1 \mathrm{mM}$ cresol red plus $6 \mu \mathrm{L}$ water). Twelve microliters of the reaction were loaded on a $12 \%$ vertical polyacrylamide mini-gel $(8 \times 10 \mathrm{~cm})$ and electrophoresed at 165 $\mathrm{V}$ for $45 \mathrm{~min}$ in $1 \times \mathrm{TBE}$ buffer $(89 \mathrm{mM}$ Tris/89 $\mathrm{mM}$ boric acid/2 mM EDTA). Gels were stained for about 2 min in $1 \times$ TBE containing $1 \mu \mathrm{g} / \mathrm{mL}$ ethidium bromide and imaged under UV light using an Ambis Imaging System (Scanalytics, Billerica, MA, USA).

The yield of soluble DNA varied with the tissue type and heating time (Figure 1). The yield was greatest from spleen. Ear punches, neonatal toes and tail snips produced similar amounts of soluble DNA. The yield of DNA increased with heating time for each of these tissues, most dramatically with spleen. However, the variation in soluble DNA among tissues and heating times had little influence on the amplification of the PCR product (Figure 2). These results suggest that the duration of heating time is not critical to the reaction out-

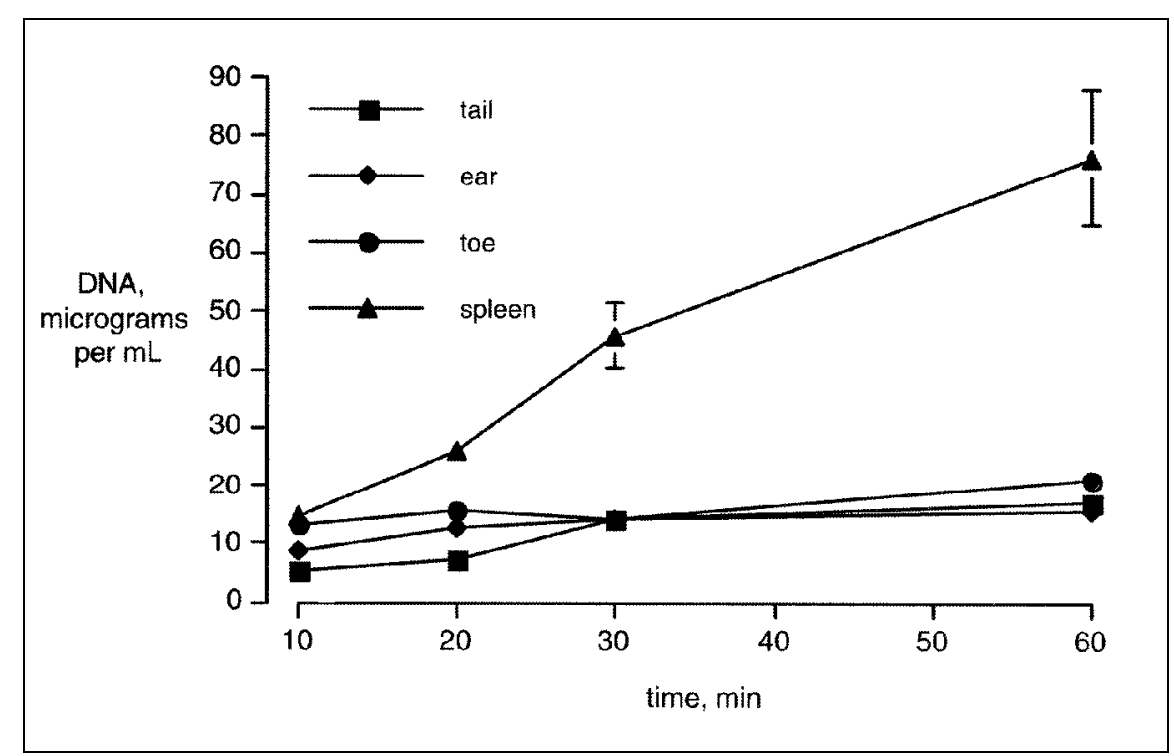

Figure 1. Effect of heating time on yield of soluble DNA prepared by the HotSHOT method. DNA was prepared by heating for $10,20,30$ or $60 \mathrm{~min}$ in $75 \mu \mathrm{L}$ alkaline lysis reagent, followed by the addition of $75 \mu \mathrm{L}$ neutralizing reagent. 
come and may be chosen for the convenience of the investigator. We used primarily neonatal toe and ear punch tissues and chose a 30-min heating time. Note also that the control DNA (Figure 2, lane $\mathrm{C}$ ) produced more nonspecific PCR product than the HotSHOT DNA. This was confirmed in another experiment that compared HotSHOT DNA to DNA prepared by other methods and found that HotSHOT produced the cleanest PCR products (data not shown).

The HotSHOT method has been used in our laboratories to amplify 39 different products, including microsatellites, up to $1.9 \mathrm{~kb}$ in length. Standard PCR conditions were used for all assays. No primer pairs failed with HotSHOT DNA. Although we usually run PCR soon after preparing the DNA, we have stored samples up to three months at $4^{\circ} \mathrm{C}$ and $-20^{\circ} \mathrm{C}$ before running PCR

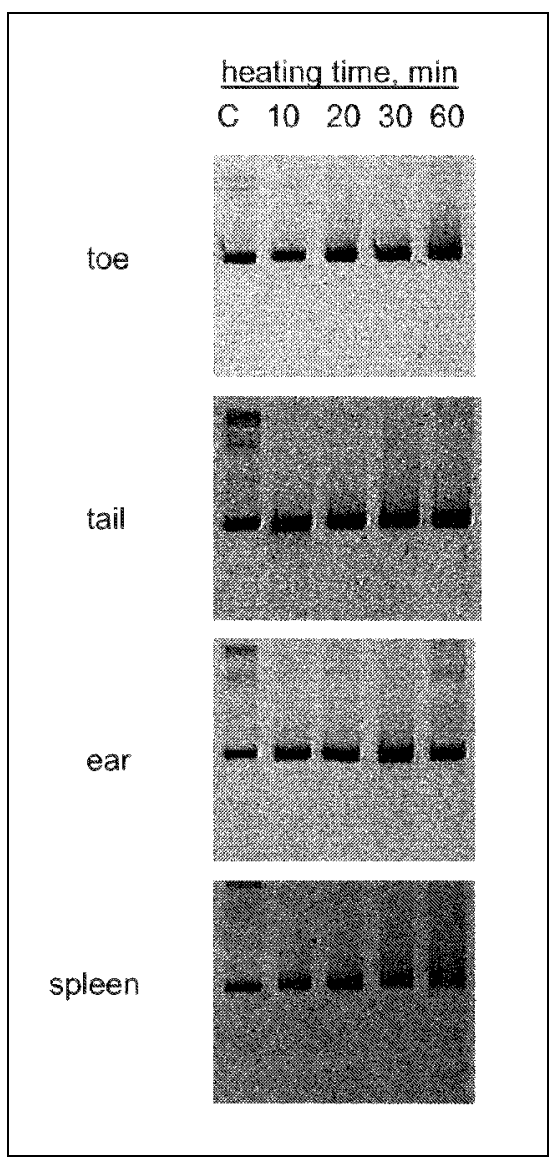

Figure 2. Effect of heating time on amplification of a 182-bp PCR product from various mouse tissue samples. Control DNA (C) was prepared by a traditional DNA extraction method. HotSHOT DNA was heated as described in Figure 1, followed by PCR amplification. and have had good results. Reviewing our records of a specific assay run with DNA prepared by traditional extraction methods and the same assay run with HotSHOT DNA, we found that 26 out of 1079 reactions failed with DNA prepared by traditional methods and only 9 out of 1011 reactions failed with HotSHOT DNA (P-value of Fisher's exact test, 0.0095), indicating that HotSHOT DNA performed slightly better than DNA prepared by traditional methods. The same reagents have also been used to prepare DNA from bacterial colonies for PCR; no heating was required for this application.

In an additional experiment, we found that HotSHOT DNA is not suitable for genotyping transgenic mice by Southern analysis. The DNA is extensively sheared and its concentration is too low. It is also possible that the DNA was not efficiently digested by the restriction enzyme because of interfering substances in the DNA preparation or because the DNA did not reanneal efficiently after it was neutralized. Although HotSHOT DNA preparation is likely to be limited to PCR applications, the savings in time and reagents over traditional DNA preparation methods is substantial, and the quality of the results is as good or slightly better than DNA prepared by traditional methods.

\section{REFERENCES}

1.Cesarone, C., C. Bolognesi, and L. Santi. 1979. Improved microflurometric DNA determination in biological material using 33258 Hoechst. Anal. Biochem. 102:188-197.

2.Rudbeck, L. and J. Dissing. 1998. Rapid, simple alkaline extraction of human genomic DNA from whole blood, buccal epithelial cells, semen and forensic stains for PCR. BioTechniques 25:588-592.

3.Strauss, W.M. 1998. Preparation of genomic DNA from mammalian tissue, p. 2.2.1-2.2.3. In Ausubel et al. (Eds.), Current Protocols in Molecular Biology. John Wiley \& Sons, New York.

Address correspondence to Dr. Gary E. Truett, Developmental Genetics Laboratory, Pennington Biomedical Research Center, 6400 Perkins Road, Baton Rouge, LA 70808,USA.e-mail: truettge@pbrc.edu

Received 15 November 1999; accepted 10 March 2000.
G.E. Truett, P. Heeger ${ }^{1}$, R.L. Mynatt, A.A. Truett, J.A. Walker and M.L. Warman' Pennington Biomedical Research Center

Baton Rouge, LA

${ }^{1}$ Case Western Reserve University Cleveland, $\mathrm{OH}, \mathrm{USA}$

\section{Choice of Microcentri- fuge Tubes Influences $T$ Cell Proliferation Assay}

BioTechniques 29:54-59 (July 2000)

Microcentrifuge tubes are widely used in life science laboratories, including those focusing on cell culture, molecular biology and microbiology. Typically holding $0.2,0.5$ or $1.5-1.6 \mathrm{~mL}$, these tubes generally provide passive support for reactions or storage of liquids. Recently, we realized that this is not always the case. We routinely perform proliferation assays with $\mathrm{T}$ lymphocyte cell lines to assess substances and media factors for inhibitory activities (1) and have observed that some sets of samples all contained some inhibitory capability. Subsequent investigation suggested that one brand of microcentrifuge tube used for storage and dilution of examined substances affected $\mathrm{T}$ cell proliferation responses. Therefore, we performed a systematic assessment of microcentrifuge tubes obtained from different manufacturers in our proliferation assay.

A human $\mathrm{T}$ lymphocyte line from peripheral blood was established and kept in culture by repeated stimulation as previously published (2). Lymphocyte proliferation was measured after anti-CD3 stimulation by a thymidine incorporation assay as previously published (1). In short, 96-well, flat-bottom plates were precoated with goat-antimouse antibody and then coated with a mouse-antihuman CD3 mAb (Ortho- 